研究課題別評価

1 研究課題名 :神経系におけるスフイココ糖脂質ミクロドメイン超分子構造の機能発現と制御

2 研究者氏名 笠原浩二

研究員 鈴木直子 研究期間 :H14.4.1. H17.3.31)

湯山耕平 研究期間 :H14.4.1 〜 H17.3.31)

3 研究の狙い:

シアル酸を含むスフイコ糖脂質であるガングリオシトは脳の発生段皆において組成力湿鿓に変化するこ とカ知られ、神経細胞分化に関わる可能性が示唆されてきた。しかい ガングリオシけは機能がまたに解明 されておらず、ポスドノ時代における重要な研究標的として残されている。我々は独自にガングリオシドが 細胞膜ミクロドメインにおいて神経細胞分化に関わるシグナル伝達分子と会合し 弚れを制御していることを 見つけた。現在このスフイコ糖脂質ミクロドメインは脂質ラフトとも呼ばれ、生体内でシグナル伝達の中継 点として働いていることか明らかになりつつり、世界的に注目を集めている。本研究は、脳神経系におけ るスフイコ糖脂質ミクロドメイノの機能を明らかにすることを研究の狙いとする。

4 研究成果 :

(1)スフイコ糖脂質会合タンパク質の同定

我々はスフインコ糖脂質ミクロドメインにおけるシグナル伝達を解明することを目的として、抗ス フインコ糖脂質抗体で免疫沈降する際に共沈してくる スフインコ糖脂質会合タンパク質」の単離を 試みた。弚の結果、小脳顆粒神経細胞において抗ガングリオシド GD3 抗体で、135kDa, 80kDa, 56/53kDa, 40kDaのタンパク質が共沈することを見つけ、弚れどれ 135kDa は GPIアンカ一型神経 細胞接着分子 TAG- 1、80kDaは src ファミリーキナーゼ基質 Csk- binding protein (Cbp)、56/53kDa は src ファミリーキナーゼ Lyn、40kDa は神経特異的三量体 G タンパク質 Go のa サブユニットで あることを見出した。

(2)TAG- 1の Lyn を介するシグナル伝達

TAG-1は免疫グロブリンスーパーファミリーに属する神経細胞接着分子で、神経突起伸長活性 を持つことが知られている。しかしTAG-1 は、GPI アンカ一型タンパク質であり膜貫通領域を持た ないことから、細胞内シグナル伝達機構について研究があまり進んでいなかた。我々は TAG-1 とLynはともにスフイコ糖脂質ミクロドメイン画分に存在し、TAG-1をリガンドまたは抗体でクロス リンクするとLyn が一過的に活性化することをすでに報告した Kasahara et al. J.Biol.Chem. 275 34701-34709, 2000)。本研究では、スフインコ糖脂質ミクロドメインでの TAG- 1 とLyn の会合を再 構成系を用いて確認し、光のシグナル伝達機構の解析を進めた。CHO 細胞にTAG- 1 cDNA を発 現させると、乥の細胞は自己凝集活性を示し TAG- 1 は接着活性を持つことがわかつた。このとき TAG- 1 はスフイコ糖脂質ミクロドメイン画分に存在し、この細胞にガングリオシドGD3 の生合成 酵素遺伝子の cDNA を共発現させると、抗ガングリオシドGD3 抗体による免疫沈降でTAG- 1 が 共沈し、スフイコ糖脂質ミクロドメインでのTAG-1 とガングリオシドGD3の会合か確認された。光 してメチルシクロデキストリン処理によるコレステロールの除去で小脳顆粒細胞のスフインコ糖脂 質ミクロドメインを破壊すると、TAG-1の Lyn を介するシグナル伝達か阻害されることから、シグナ ル伝達がスフインコ糖脂質ミクロドメインでおこっていることが証明された。また小脳顆粒細胞をス フインコ糖脂質生合成酵素阻害剂であるISP-1 て処理しても同樣にシグナル伝達が抑制されるこ とから、TAG-1のシグナル伝達にスフイコ糖脂質が必要であることがわかつた。 
(3)Cbp のシグナル伝達

$\mathrm{Cbp}$ はスフイコ糖脂質ミクロドメイン膜貫通タンパク質で、 src ファミリーキナーゼの基質である ことが知られている。CHO 細胞に発現させた Cbpはスフインコ糖脂質ミクロドメイン画分に存在し、 Lyn を共発現させるとCbp がチロシンリン酸化され、非活性型の Lyn ではリン酸化されないことか ら、Cbpが Lynの基質になることが確認された。TAG-1は神経突起伸長や神経束形成に関与し、 実際に乥れが機能していると考えられる発生初期段階におけるシグナル伝達を成体期と比較した ところ、発生初期段階と成体でLyn はどちらともスフインコ糖脂質ミクロドメインに存在していたが、 発生初期段階でのみスフイコ糖脂質ミクロドメインにおける Lyn 活性化および Cbp チロシンリン 酸化が見られた。これらの結果は、Cbp は TAG-1のシグナル伝達の下流分子であることを示して いる。リ酸化 Cbpは、src ファミリーキナーゼの負の制御因子であるCsk を細胞質からスフイゴ 糖脂質ミクロドメインに移行させることが知られていることから、Cbp は Lyn のネガテイブフィード ツク調節に関与しているものと考えられる。

\section{(4)Goa のシグナル伝達}

三量体 $\mathrm{G}$ タンパク質は活性化に伴ってa サブユニットと $\mathrm{y}$ サブユニットこ分かれるが、不活 性状態では両者ともにスフインコ糖脂質ミクロドメイン外に存在するのに対し、非水解性 GTP アナ ログで活性化してやるとa サブユニッけみがスフインコ糖脂質ミクロドメイン画分に移行すること がショ糖密度勾配遠心法により明らかとなつた。興味深いことに、Goa のスフインコ糖脂質 ミクロド メインへの移行はラッ小小脳の発生初期にのみ見られ、成体では見られなかった。百日咳毒素処 理でGo を不活化すると、光のGoa の移行は見られなくなった。さらに小脳顆粒細胞に発現してい るG タンパク質共役受容体 CXCR4の生理的リガントであるSDF-1a を添加すると、Goa の活性 化、脂質ラフ円の移行、成長円錐の退縮がおこることを見つけた。これらの結果は、活性化に伴 う Goa のスフイコ糖脂質ミクロドメインへの移行は SDF-1a による成長円錐の退縮に関与して いることを示唆している。

(5)スフイコ糖脂質会合タンパクと神経成長円錐

本研究で同定したスフイコ糖脂質会合タンパク質 TAG- 1, Lyn, Cbp, Goa はすべて成長円錐 画分に存在していた。これは成長円錐のスフインコ糖脂質ミクロドメインにおけるシグナル伝達が、 神経突起形成の調節に関わっていることを示している。

\section{5 自己評価 :}

ガングリオシドが神経突起伸長に関わっていることは以前より知られていたが、光のメカニズム についてはまだよ〈わかっていなかった。光の中で本研究は、抗ガングリオシ惭体による免疫沈 降というオリジナルな方法を用いてガングリオシドが神経突起伸長に関わっている分子と直接会 合していることを示し、ガングリオシドが产のシグナル伝達の場を提供していることを明らかにした。 機能解明の困難だつたガングリオシ研究に新たな道を開いたものと考えている。

スフインコ糖脂質ミクロドメインの研究は盛んにおこなわれるようになつたが、弚の中でスフイン コ糖脂質自身の役割についてはほとんど注意を払われてこなかつた。最近、ガングリオシ性合成 酵素遺伝子ハックアウトマウスが神経系において樣々な表現型を示すことがわかってきた。しかい

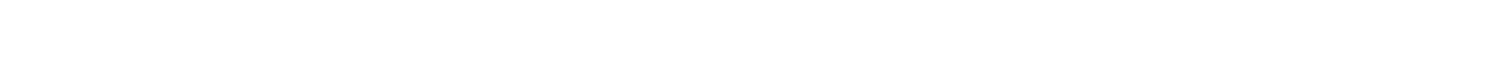
と考えられる。本研究て得られた成果の多〈を論文発表の形までもっていけなかつたことは、多いに反省すべ き点である。

\section{6 研究総括の見解 :}

研究は順調に進んでいる。脳を特徵付けるガングリオシドの機能解明に向かって新たな一歩を 進めたことは評価し得る。今後の課題として、対象としているミクロドメインの動的な、機能的超分 
子構造の解析にも更なる一歩を進めて欲しい。今後は、単なるシグナル分子系列の同定に終始 しないように気をつけ、掘り下げた密度の高い研究を展開すべきであろう。ラフトコンセプト使用 には批判も多く、注意して使用すること。発表には前向きて対処されたい。

\section{7 主な論文等 :}

\section{論文 総説}

1 .Yamauchi, S., Tokita, Y., Aono, S., Matsui, F., Shuo, T., Ito, H., Kato, K., Kasahara, K., Oohira, A. Phosphorylation of neuroglycan $\mathrm{C}$, a brain-specific transmembrane chondroitin sulfate proteoglycan, and its localization in the lipid rafts.

J. Biol. Chem. 277 20583 20590, (2002)

2 .Kasahara, K., Watanabe, K., Kozutsumi, Y., Oohira, A., Yamamoto, T. and Sanai, Y. Association of GPI- anchored protein TAG- 1 with src- family kinase Lyn in lipid rafts of cerebellar granule cells. Neurochemical Res. 27 823 829, (2002)

3. Yuyama K, Sekino- Suzuki N, Sanai Y and Kasahara K Lipid rafts in cellular signaling and disease. Trend.Glycosci.Glycotech. 15(83) 139-151 (2003)

4 . Hiramatsu T, Sonoda H, Takanezawa Y, Morikawa R, Ishida M, Kasahara K, Sanai Y, Taguchi R, Aoki J, Arai H.

Biochemical and molecular characterization of two phosphatidic acid- selective phospholipase A1s, mPA- PLA1 alpha and mPA- PLA1 beta.

J. Biol. Chem. 278 49438- 49447, (2003)

5 . Yuyama K, Sekino- Suzuki N, Sanai Y and Kasahara K

Translocation of Activated Heterotrimeric G Protein Go · to Lipid Rafts in Cerebellar Neurons (submitted)

6 . Hirai M, Koizumi M, Hirai H, Hayakawa T, Yuyama K, Suzuki N and Kasahara K

Structures and dynamics of glycosphingolipid- containing lipid mixtures asraft models of plasma membrane

J .Phys.: Condens.Matter (in press)

7 .Sekino- Suzuki N, Yuyama K, Sanai $\mathrm{Y}$ and Kasahara K

Tyrosine phosphorylation of $\mathrm{Cbp}$ by ligation of GPI- anchored neuronal adhesion molecule TAG- 1 in lipid rafts.

(in preparation)

\section{8 .笠原浩二 佐内豊}

神経系細胞膜ラフトとシグナル伝達」

蛋白質核酸酵素 共立出版 47(4) 333-337 (2002)

9 .笠原浩二、佐内豊 脂質ラフトと複合糖質」

蛋白質核酸酵素 48(8) 1164 - 1170 (2003)

10 .鈴木直子、湯山耕平、佐内豊、笠原浩二 神経系における脂質マイクロドメイン」

蛋白質核酸酵素 49 2397- 2403 (2004)

11 . 湯山耕平、鈴木直子、佐内豊、笠原浩二 神経細胞接着分子 TAG- 1の脂質ラフトを介するシグナル伝達」

膜 日本膜学会編) 30 印刷中) 


\section{受賞}

湯山耕平 ダループメンバー)

平成 16 年 第 7回日本糖質学会ポスター賞受賞

三量体 G タンパク質 Go の神経細胞膜ラフトにおけるシグナル伝達とガングリオシド」

\section{招待講演等}

1 .笠原浩二、佐内豊

フォスファカンの脂質ラフトにおけるTAG- 1/Lyn を介するシグナル伝達

第 45回日本神経化学会 2002 年 7 月 17- 19 日札幌 ヒンポジウム)

Neurochemical Research 28(7) 1082 (2003)

2 .笠原浩二

スフインコ糖脂質ミクロドメインの構造と機能

第 47 回 FCCAセミナー第 9回グライコサイエンス若手会

埼玉 2002年 9 月 14 日 招待講演)

3 .笠原浩二、渡辺和忠、大平敦彦、小堤保則、佐内豊

小脳顆粒細胞膜ラフトを介する GPI アンカ一型神経細胞接着分子 TAG-1の機能発現

第 75 回日本生化学会大会 2002.10.16. 京都 ヒンポジウム)

4 . 笠原浩二

神経細胞膜ラフト機能制御とコレステロール

第 26回日本神経科学会大会 2003.7.23. 名古屋 ヒンポジウム)

Neuroscience Research 26 Supplement 1 S11 (2003)

5 .Kasahara K.

"Signal transduction by GPI- anchored neuronal cell adhesion molecule TAG- 1 in lipid rafts"

"Symposium on Glyco- Neurobiology- - - Glycolipids, Glycoproteins, and other Glycoforms" - A

Satellite Meeting for the 2003 International Society of Neurochemistry Annual Meeting (February 8 to 11, 2004, Taipei, Taiwan) 招待講演)

6 . 笠原浩二、佐内豊

神経細胞接着分子 TAG- 1の脂質ラフトを介するシグナル伝達

日本膜学会第 26年会 2004.5.20. 東京 ミニシンポジウム)

7 .Yuyama K, Suzuki N, Sanai Y, Kasahara K

Activation- dependent recruitment of trimeric $\mathrm{G}$ protein Go $\cdot$ to lipid rafts in cerebellar granule neurons.

第 77回日本生化学会大会 2004.10.16 横浜 ワークショ゙プ)

弚の他

国外発表 7 件

国内発表 18件 